\title{
EchoGéo
}

$47 \mid 2019$

Nouvelles géographies de la collecte

\section{New Geographies of Collection: Crossed perspectives on modern "gatherers"}

Introduction

Lucie Dejouhanet and Rémi de Bercegol

\section{OpenEdition}

\section{Journals}

Electronic version

URL: https://journals.openedition.org/echogeo/17468

DOI: $10.4000 /$ echogeo. 17468

ISSN: 1963-1197

\section{Publisher}

Pôle de recherche pour l'organisation et la diffusion de l'information géographique (CNRS UMR 8586)

\section{Electronic reference}

Lucie Dejouhanet and Rémi de Bercegol, "New Geographies of Collection: Crossed perspectives on modern "gatherers"', EchoGéo [Online], 47 | 2019, Online since 21 April 2019, connection on 10 August 2021. URL: http://journals.openedition.org/echogeo/17468 ; DOI: https://doi.org/10.4000/echogeo. 17468

This text was automatically generated on 10 August 2021

EchoGéo est mis à disposition selon les termes de la licence Creative Commons Attribution - Pas d'Utilisation Commerciale - Pas de Modification 4.0 International (CC BY-NC-ND) 


\section{New Geographies of Collection: Crossed perspectives on modern "gatherers"}

Introduction

\section{Lucie Dejouhanet and Rémi de Bercegol}

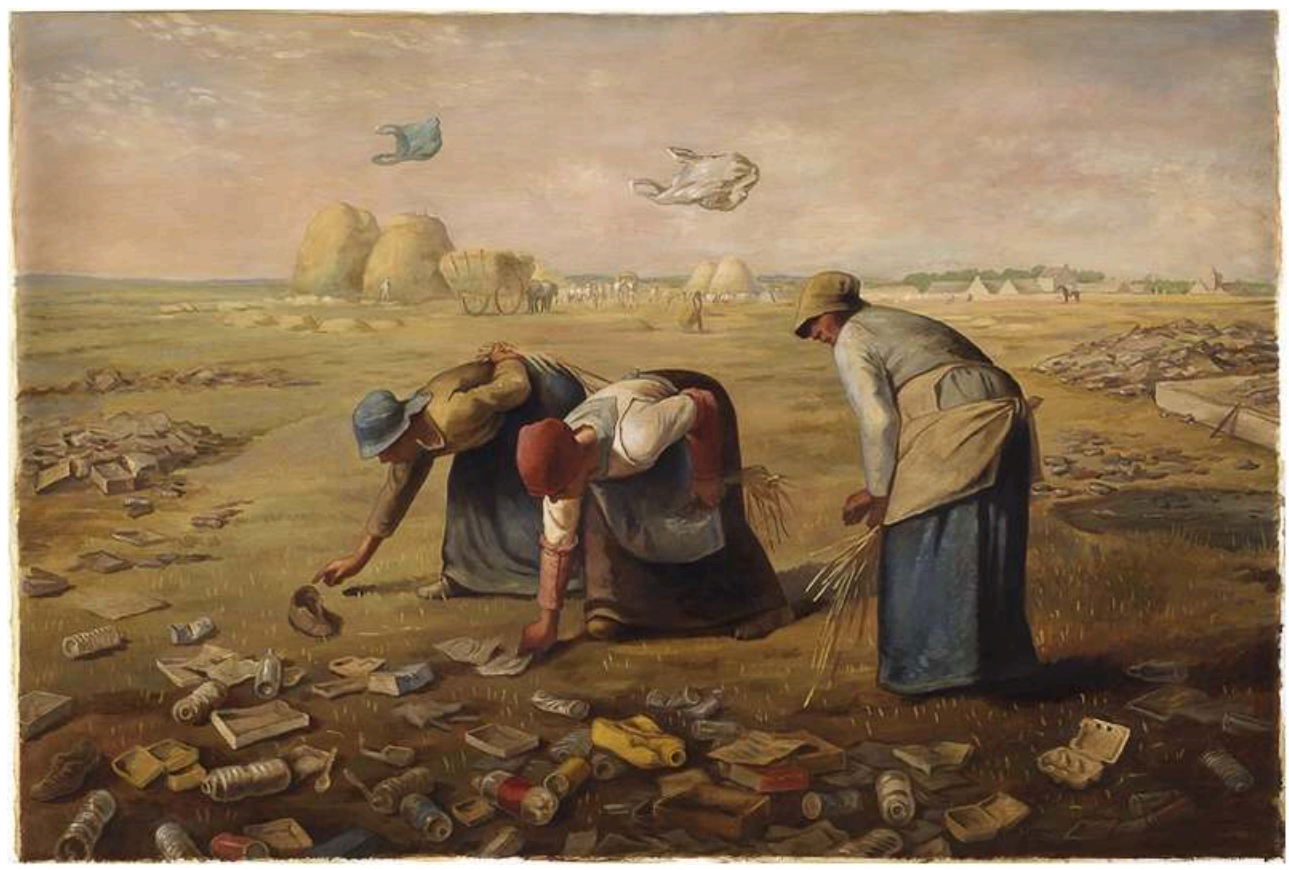

Source: (c) E. Leclerc and Nettoyons la nature. Illustrator: Martin Hargreaves, Marie Bastille agency

To collect: $14^{\text {th }}$ century. Derivation of collection. To gather, to assemble, to collect something.

(Synonyms: to pick, to gather, to glean, to recover, to extract). 
[Source: Dictionary of the Académie Française, $9^{\text {th }}$ edition, 2019].

1 In 2017, British illustrator Martin Hargreaves, who specialises in pastiches of works by the great masters, produced a version of Jean-François Millet's masterpiece The Gleaners (1857). This famous painting shows three peasant women gleaning a field of stray stalks of wheat after the harvest, which we can glimpse loaded onto carts in the background. In Hargreaves' reworking, these peasant women are picking up... rubbish. Used by a major French distribution chain as part of an advertising campaign for the environment, this composition was displayed in Paris metro stations, and published in the press and on the Internet. His version serves its purpose on two fronts, successfully conveying both the awareness-raising message commissioned by the sponsor and bringing together two activities that, at first glance, seem unrelated: gleaning agricultural leftovers and recovering refuse. In both cases, this means collecting up what other people have dumped, things of no apparent value. From stray stalks of wheat to rubbish, the gleaners continue gleaning and recovering leftovers.

2 From the Latin colligere (to collect, to pick, to gather, to harvest, to assemble), the word "collection" here is intended as an umbrella term to qualify the processes of collecting recoverable materials available in particular environments. The fruits of this collection are therefore a resource, a priori renewable. It is not the result of processing raw materials: it is something that already exists in nature and in the environment. It is a product that the gatherer finds, he knows the places where it is most abundant, and something that he can even help to regenerate. But the collection activity itself is one part luck, one part uncertainty.

3 Extracting existing resources from the environment instead of producing them is often seen as a relic of the past, an activity associated with poverty or with the primitivism of evolutionist theories; but as Anna L. Tsing warns, "it would be a mistake to see the Matsutake [mushroom] trade as a relic of the past; this is the mistake made by people blinded by progress." (Tsing, 2017, p.32). It is a practice which still exists in our capitalist societies; it is even on the increase, whether as a way of surviving poverty, or as a lifestyle choice for living in closer contact with the environment, or to meet the growing wild plant requirements of the cosmetics industry, or to feed the flourishing recycling market. Collection activities actually contribute to dynamic economies because they are at the root of production chains, governed by criss-crossing networks of relationships and forming part of unexpected multi-scalar flows.

In this thematic dossier of EchoGéo, we intend to examine the "collection" practices for plants and detritus alike in different spaces. From gathering ears of wheat left over after the harvest to gathering waste, from picking medicinal plants to urban gleaning, putting diverse forms of collection in perspective sheds light on the ambivalent nature of a multiform practice. It is a legacy of the long history of humanity, where foraging has been considered "humanity's first adaptation for its success" (Lee et al., 1999), and at the same time something terribly contemporary in a "peri-capitalist economy" (Tsing, 2017). Rooted in a certain "tradition", collection carries with it the changes taking place in our world. This edition invites readers to ponder its current forms, the way it operates in and is integrated into the globalised economy, and what this means in a world that has always been familiar with it... but not actually all that familiar. 


\section{Fresh research into collection practices}

5 Whatever the environment, whether on a tip or in a forest, scavengers and foragers, whether organised or not, extract resources. Back in the 1970's, Larissa Adler Lomnitz was already describing waste recyclers in Mexico as "hunter-gatherers in the urban jungle" (1975). The results of collection find their way into the domestic, commercial and even industrial sectors. The organisation of these sectors and the relationships between the different stakeholders involved has been the subject of an increasing amount of research, which highlights the processes by which collectors adapt and find their niche in the global economy. On the one hand, research into urban waste is multiplying (Jeanjean, 2016; Florin and Cirelli, 2015). It explores the mechanisms for waste recovery, the renegotiation of power relationships in sectors, and the challenges of finding a framework for these often informal activities, particularly in southern latitudes (Bercegol et al., 2017). Seen as an economic asset, waste is characterised in this respect by competition and symptomised by conflicts of ownership (Cavé, 2013; Gidwani, 2012). In towns and cities with pronounced inequalities, the collection economy and its associated proto-industrial processing sectors are still major sources of employment (Florin, 2015). Many pieces of research therefore advocate better regulation of this economy where recycling chains are not well controlled, in order to introduce social and environmental standards (Le Meur, 2016). On the other hand, research into plant picking for commercial purposes highlights changes in this activity linked to growing demand, issues linked to the quality of plant raw materials (Springer, 2015; Blaikie, 2014), the deployment of cross-border networks which are often difficult to control (Saxer, 2013) and changes in how the product gathered across the sector is perceived (Mercan, 2012; Garreta, 2007). Recent research focuses on describing gatherer techniques and worlds (Pinton et al., 2015; Julliand, 2008). The brilliant work of A. L. Tsing likewise illustrates the multiple criss-crossing strands that characterise the sector, using the example of Matsutake mushrooms gathered in Oregon by low-paid workers and then retailed at exorbitant prices in luxury Japanese greengroceries (Tsing, 2017). This interweaving of strands and spaces is also examined in the Sur l'Ecrit section of this issue in the interview with Mathieu Quet, author of a fascinating survey of the logistics system underlying medicinal product flows. In these two equally exciting studies, sectors are characterised by the interweaving of the legal and the illicit, the formal and the unrecognised. Similarly, although the collection of waste or plants is the basis of sectors that create value, one cannot help but notice that the practice is being relegated to a marginal status. On both sides of the plant gatherer / waste gatherer comparison, we find social groups who are for the most part poor and whose professions, largely unrecognised by governments, are qualified as informal.

\section{"Gathering is the stigma of poverty" (Larrère, 2012, p. 40): being forced to live on the margins, or choosing to.}

6 Jean-François Millet's oil painting The Gleaners, mentioned at the beginning of this article, is held in the prestigious Musée d'Orsay collection and is today considered a priceless masterpiece. However, when the artist presented it for the first time in 1857 at the "Salon", the opinion of critics was at best lukewarm. The "three gleaners have 
preposterous pretensions: they are posing as the three Fates of Poverty", wrote French author and critic Paul de Saint-Victor (1825-1881). The classic composition of the painting, almost religious in style but showing a bucolic scene, was seen as a moral insult. Gleaning was at that time considered as a survival tactic used by poor populations, something harking back to medieval customary law which permitted anyone who so wished to pick up harvest surplus left lying on the ground, thus supplementing their diet for free. Often confused with raiding (the theft of crops yet to be harvested), nowadays just as in the past, the act of bending down to pick up what somebody else has left behind is often seen negatively in our industrialised societies. However, the term "gleaning" is still in use today and no longer only in the countryside but also in towns, to mean scavenging for waste left in bins. This is a practice reclaimed by, for example, the Paris rag-and-bone association Amélior, or the gleaners wonderfully depicted by Agnès Varda in her documentary The Gleaners and I (2000). Moreover, it is from apples scrumped from abandoned orchards in Burgundy that Mathias Faurie, handmade cider producer, makes most of his cider, as he explains in an interview in the Sur le Métier section.

7 As poor, largely ignored workers, gatherers are not therefore a homogenous group and their professionalization still tends to diversify their profile. The articles in this edition do not focus on autochthonous populations and their gathering practices: the gathering practices we address here seem far removed from the straitjacketed prejudices which reduce them to a primitive economy or an "ethnic" practice. With one exception: Lena Springer's article, which describes the process of recognising the expertise and practices of plant gatherers in the mountains of north-west China. Although the gathering technique is indeed rooted in a strong, regional, cultural identity, the efforts being made there to raise its profile involve the construction of more elaborate categories than a simple ethnic idiosyncrasy. And while in southern India the collection of non-timber forest products is a practice reserved for scheduled tribes, gatherers of medicinal plants, including from forests, actually come from different rural populations (Dejouhanet, 2014). Similarly, although we might think that refuse recovery in Indian towns and cities is done only by members of the Untouchable caste, it is actually carried out by a far larger variety of social groups (Gill, 2009). In fact, gatherers resist any kind of stereotyping.

8 The increasing demand for plants is also driving new populations to take up this activity and to join trading networks. As we can see in Quebec, where Sabrina Doyon differentiates between two forager profiles, depending on their level of engagement in this activity: foragers for whom it is their main source of income, and foragers for whom it is an income supplement. The former have the expertise and financial resources permitting them to pick non-timber forest products from vast extensions of land, and they choose this profession because they want to stay in their country, and because they love what they do. As for the "additional" gatherers, they go picking on an ad hoc basis to supply small businesses, or periodically join the picking camps which supply large volumes of raw materials to processing industries. They do not necessarily declare their picking activity and their economic situation is often unstable, because they rely on different sources of income. The practices of this population vary: they choose their outlets according to opportunities, and can choose not to do any picking at all depending on the year, the season, or the remuneration offered. 
9 This distinction, which doubtless requires nuancing, between "professional" pickers and "non-professional" ones, lies at the heart of the project to formalise picking in France by the AFC (French Association of Professional Pickers), presented by claire Julliand et al. "Professional" pickers understand the need to adopt sustainable, environmentally-friendly picking practices, whilst their non-professional counterparts, tempted by the potential revenue, engage in picking activity that makes no consideration of the long or even medium-term management of this resource. Formalisation of the picking profession therefore creates conflict between sustainable resource management and predation, bad practices serving to define how environmentally-friendly picking should be done. In a sense, we find a similar categorisation between "good recyclers" and "bad recyclers" among scrap pickers in the Paris region, described by Bénédicte Florin and Pascal Garret: the precariousness of some collectors does indeed make other collectors look down on them, regardless of their techniques. Implicitly, these representations raise questions about the ambivalence in collection activity between actively choosing to live on the margins, or having no choice.

\section{"The res derelictae have become a shared resource" (Glémain, 2013, p. 157): resources to be secured.}

Poorly defined by-laws make the question of access to collection particularly important. Resources are available in the environment according to whether it is a system of club goods, where particular species are reserved (mushroom picking licences, rights in particular territories to a particular category of picking, delegation of waste collection to a single private operator in an area, etc.), or a free-access, firstcome first-served system. Approaches to collection can therefore be highly conflicting in terms of defining rights to resources, competition over their collection in a given space, and the unequal distribution of the wealth gained from their sale and processing, particularly when there is little State regulation. In urban areas, res derelictae is theoretically considered res nullius (just as ruderal plants are): once their owner decides to get rid of them, anyone can subsequently appropriate them, as they enter the system of free-access goods. In fact, people who rummage through dustbins in search of food or goods are often considered to be violating the rights of the exowners of the waste, as illustrated by the experience of Parisian freegan Jeanne Guien. Likewise, B. Florin and P. Garret provide us with an insight into scrap pickers in the Paris region who have such a dreadful reputation, like the Roma population among them who are often labelled thieves. There is thus competition for access to the resource between the recyclers and the former owners of the waste, between the collection companies who benefit from a certain social and symbolic legitimacy for undertaking their business and the informal recyclers, who generally supply waste sorting centres or scrap merchants, and between the recyclers themselves, who employ strategies for ensuring that they are the first to arrive at the waste depot.

11 A comprehensive system of regulation is gradually being introduced to provide a framework for picking wild plants, aiming on the one hand to protect vulnerable species and on the other, to protect specific spaces from resource exploitation. Recommendations regarding picking practices and resource management have been made in the past, but have enjoyed little success. Today, it is the charters drawn up 
using participatory methods - for example, the AFC national picking charter ${ }^{1}$ or the eco-picking charter in Morvan and Burgundy ${ }^{2}$ - which aim to control and structure picking practices. In the context of competition for resources, recyclers see the formalisation of their collection activities as a means of allowing them to exist when facing, for example, companies who hold contracts with municipal authorities, as is the case of the collectors in Latin America described by Mélanie Rateau and Luisa Tovar. However, this formalisation of practices, professions and sales networks seems to be creating a dual tension, which no doubt accounts for the mixed opinions held by foragers in Quebec (S. Doyon) and in France (C. Julliand et al.) regarding this process. On the one hand, formalisation does permit entry to a regulated system and official recognition of the profession, but on the other, it limits the freedom which characterises the profession and its practices (A.L. Tsing presents mushrooms as "trophies of freedom"). Formalisation transforms the collection practices and status of recyclers, although these groups have little organisation or social capital, which sometimes marginalises them still further as Mathieu Durand and Fabio De Oliveira Neves explain, drawing on experiences of formalisation in Latin America. Rather than formalisation, what these workers demand above all is recognition of their existence. It is this humanised perspective of a right to collect that is highlighted in the In Images section, which features some of the photographs in the exhibition "Waste in Pictures" presented by Claudia Cirelli $e$ t al.

\section{"Insecurity is the condition of our times" (Tsing, 2017, p. 55): on collection as a form of resistance}

Raphaël Larrère (2012) analysed mushroom picking in Margeride between 1970 and 1980 from three perspectives: as a strategy for surviving poverty, as a symbolic repossession of the land, and as one of the few leisure pursuits enjoyed by isolated rural populations. In the case of gatherers in Margeride, mushroom picking was a way for the rural population to combat their increasingly insecure living conditions, dispossessed of swathes of their land being bought up and progressively reforested: although the local elites that be had taken their land, the rural population still had their mushrooms (Larrère, 2012). The symbolic claim associated with foraging and making use of resources in the spaces we inhabit can be found in numerous situations: in Quebec, where the development of picking activities is part of a regional development initiative and efforts to encourage young people to stay "in their region" (S. Doyon), in China where valuing the expertise of pickers goes hand-in-hand with reinvestment in local traditions and the Daoist religion, unlike previous campaigns which sought to homogenise culture (L. Springer), or in the Paris region where rehomed Roma families continue their scrap picking activities, even though a condition of their being rehomed was to cease these activities (B. Florin and P. Garret). Foraging and collecting thus appear to be a symbol of resistance in an insecure world (Tsing, 2017).

Informal activities are difficult to regulate, so public policies therefore encourage the formal organisation of collector groups, collector practices and collection-related activities. However, Christer Norström (2003) defined foragers in terms of the idea of autonomy: group and individual autonomy. So, is formalisation a standardisation which restricts the scope of this resistance practice, or is it a way of preserving the freedom to exercise this profession, a right to live on the margins in an increasingly standardised 
world? What space is left for collection, in a world where control of activities is becoming ever tighter and rules ever stricter? Is there any space left for living on the margins? Protected spaces, "no-go" areas in mushroom forests set aside exclusively for holders of official picking licences (Barreau, 2014; Tsing, 2017), urban expansion, deforestation in southern latitudes, installation of devices for increasing security in towns and cities, etc., all seem to be constricting the space for freedom that living on the margins offers, pushing it ever further away. Although A.L. Tsing claims that the sustainability of societies must be sought in the margins, where instability encourages reinvention of the ways of making a world, she also suggests taking a fresh look at how margins are defined: in the heart of industrialised, exploited spaces, where Progress believes that it has used up everything that can be made use of. Seen from this perspective, urban picking practices find their meaning. In the research paper by Marc-Alexandre Tareau et al., he shows how people newly arriving in Cayenne from outlying rural regions bring their medicinal plant use practices with them; and to keep them alive, they look for plants that grow in the urban environment. Even though they obviously cannot find all the species for their pharmacopoeia, they employ picking strategies in the urban space and its suburbs to seek out the main species they need, which often grow wild. So they explore wasteland and derelict urban areas and pick from tree branches reaching over garden fences, creating a picking space in the form of an archipelago of picking locations dotted across the city.

This appropriation of urban resources for picking can be compared with the urban gleaning and scavenging for food that were the subject of Agnès Varda's documentary in 2000. New forms of urban picking are also emerging today: gathering food plants is a growing practice in American and European towns and cities, as is freeganism, which is a militant, anti-capitalist stance involving rummaging through waste bins to find food. The adaptation to the urban context of plant gatherers in French Guyana and the search for new food resources in the urban environment by pickers in New York, presented to us by Flaminia Paddeu, are deliberate picking practices used to champion another way of seeing the world and the desire to fend for oneself. In a criticism of so much food waste, freegans like J. Guien live off the economic system; they survive through using this waste while at the same time decrying it, they also are feeding themselves in the "ruins of capitalism". As for pickers of urban plants, they are reinventing towns and cities by giving value back to wild nature spaces: spaces that have escaped control by town planners because, in the view of the latter, they are of no value. The Oregon pickers described by A. L. Tsing carry out their activities in deteriorated environments where new bio-partnerships have enabled Matsutake mushrooms, a variety which fetches a high price on world markets, to thrive. Similarly, collectors of waste, the products and survivors of the world of perishables, at first glance seem to be marginalised and outside the system. However, they are in fact strongly rooted in a capitalist system which has, for example, turned plastics recycling into a global economic phenomenon. It only goes to show that these new types of collecting among the ruins are a way of moving beyond and giving value even to damaged environments, of surviving and offering a new way of thinking about the world ${ }^{3}$. 


\section{Conclusion}

15 "World-making projects emerge from practical activities of making lives; in the process these projects alter our planet. To see them, in the shadow of the "anthropo-," we must reorient our attention. Many preindustrial livelihoods, from foraging to stealing, persist today. And new ones (including commercial mushroom picking) emerge. But we neglect them because they are not a part of progress. These livelihoods make worlds too-and they show us how to look around rather than ahead." (Tsing, 2017, p. 58).

16 This thematic dossier of EchoGéo proposes shifting our focus, as suggested by A. L. Tsing, to discern these other ways of making the world, these multiple worldmaking projects that straddle each other, ignored by the linear march of development and progress. Foraging thus becomes a lens, a prism through which to inspect the social, economic and cultural developments of our times. The large divide between foraging for plants and recovering waste is only apparent: putting it in perspective proves to be a gateway for thinking about what foraging and recovering mean today. The comparison of collection systems and spaces that, superficially, appear very different, in fact reveals interesting similarities between them, which facilitate understanding the meaning of the act of collection itself.

Let's take a final look at our three gleaners. Bending over towards the ground, each of them represents a stage of this ancestral foraging activity. Whilst the one on the right is looking and searching, the one on the left has already found, her finger pointing towards the stray stalk/piece of refuse, and the one in the middle is picking up a piece. What makes this painting a masterpiece is not only that it turns the hierarchy of genres on its head, which might have shocked the less discerning critics, but also and above all the artist's ability to give these gleaners dignity, "emblematic value devoid of any miserabilism" (Musée d'Orsay description). Although not aspiring to such lofty pretensions, this dossier of EchoGéo nevertheless aims to focus on and provide an insight into collection, what it is and what it permits and, setting aside preconceived notions, to analyse what it reveals as a force for joining diverse spaces together and helping to build a world.

\section{BIBLIOGRAPHY}

Blaikie C., 2014. Making medicine: Pharmacy, exchange and the production of Sowa Rigpa in Ladakh. Thèse de doctorat en anthropologie, Université de Kent.

Barreau G., 2014. Boletus : fructus, usus et abusus. Cahiers d'Etudes Forêt, Environnement et Société, $n^{\circ} 24$ ("Les usages non ligneux de la forêt"), p. 80-86.

De Bercegol R., Cavé J., Nguyen Thai Huyen A., 2017. Waste Municipal Service and Informal Recycling Sector in Fast-Growing Asian Cities: Co-Existence, Opposition or Integration? Resources, vol. 6, n 4, 70. https://doi.org/10.3390/resources6040070 
Cavé, J. 2014. Who owns urban waste? Appropriation conflicts in emerging countries. Waste Management and Research, $\mathrm{n}^{\circ} 32$, p. 813-821.

Dejouhanet L., 2014. Secteur informel et réseaux de commercialisation des plantes médicinales au Kérala (Inde). Économie rurale, $n^{\circ} 343$, p. 53-70.

Florin B., 2015. Les chiffonniers du Caire. Soutiers de la ville ou businessmen des ordures? Ethnologie française, $\mathrm{n}^{\circ} 153$, p. 487-498.

Florin B., Cirelli C. (dir.), 2015. Sociétés Urbaines et déchets. PUFR, 452 p.

Glémain P., 2013 Economie des res derelictae et gestion solidaire des déchets. Les écocycleries, des entreprises d'appropriateurs solidaires. Management \& Avenir, $n^{\circ} 65$, p. 154-168. https:// www.cairn.info/revue-management-et-avenir-2013-7-page-154.htm

Jeanjean A., 2016. Peindre la voix, écrire le déchet. Techniques \& Culture [En ligne], nº 65-66 ("Réparer le monde : excès, reste et innovation"), p. 310-321. http://journals.openedition.org/tc/ 8075

Le Meur M., 2016. Sous la montagne de plastique, une mine d'or ? Le mythe du recyclage à l'épreuve d'une filière vietnamienne. Techniques \& Culture [En ligne], nº 65-66 ("Réparer le monde : excès, reste et innovation"), p. 202-205. http://journals.openedition.org/tc/7951 Lee R.B., Daly R., Heywood Daly R., 1999. The Cambridge Encylopedia of Hunters and Gatherers. Cambridge University Press, $511 \mathrm{p}$.

Lomnitz L.A., 1975. Cómo sobreviven los marginados. Mexico, Siglo XXI Ed., 229 p.

Garreta R., 2007, Des simples à l'essentiel. Toulouse, Presses Universitaires du Mirail, 368 p.

Julliand C., 2008. Itinéraires de cueillette : cheminement au cœur et aux marges d'une pratique sociale, économique et symbolique. In Hallé F., Aux origines des plantes, Paris, Fayard, p. 502-529.

Larrère R., 2012. Cueillettes, menues glanes et pauvreté. In Dalla Bernardina S., L'appel du sauvage. Refaire le monde dans les bois. Rennes, Presses Universitaires de Rennes, p. 33-41.

Mercan A., 2012. La route du cordyceps. Autrepart, n 63, p. 89-105. https://www.cairn.info/ revue-autrepart-2012-4-page-89.htm

Pinton F., Julliand C. et Lescure J.-P., 2015. Le producteur-cueilleur, un acteur de l'interstice? Anthropology of food [En ligne], S11. http://journals.openedition.org/aof/7902

Saxer M., 2013. Manufacturing Tibetan Medicine. The Creation of an Industry and the Moral Economy of Tibetanness. New York, Berghahn, 304 p.

Springer L., 2015. Collectors, Producers, and Circulators of Tibetan and Chinese Medicines in Sichuan Province. Asian Medicine, vol. 10, n 1-2, p. 177-220. doi:10.1163/15734218-12341357

Sting A. Lowenhaupt, 2017. Le champignon de la fin du monde. Sur la possibilité de vivre dans les ruines du capitalisme. Paris, La Découverte, 416 p. [Traduction de l'ouvrage publié en 2015 The Mushroom at the End of the World: On the Possibility of Life in Capitalist Ruins].

Varda A., 2000. Documentary Film. Les glaneurs et la glaneuse. Ciné Tamaris, $82 \mathrm{mn}$.

\section{NOTES}

1. http://www.cueillettes-pro.org/L-etude-Charte.html (accessed on 31 March 2019). 
2. http://www.parcdumorvan.org/fic_bdd/pdf_fr_fichier/1149613688_ECO_CUEILLETTE.pdf (accessed on 31 March 2019).

3. The sensitive approach unconditionally associated with picking wild plants is not much in evidence here. It could, however, be brought legitimately closer to the philosophy and cosmology of recycling and recovering, whether of waste or of discarded food.

INDEX

Subjects: Sur le Champ - Sur le Terrain

\section{AUTHORS}

\section{LUCIE DEJOUHANET}

Lucie Dejouhanet, lucie.dejouhanet@orange.fr, is a Senior Lecturer at University of Antilles and a member of AIHP-GEODE laboratory, EA 929. She recently published :

- Dejouhanet L., 2014. Supply of Medicinal Raw Materials. The Achilles Heel of Today's

Manufacturing Sector for Ayurvedic Drugs in Kerala. Asian Medicine, vol. 7, n 3, p. 206-235.

- Dejouhanet L., 2014. Secteur informel et réseaux de commercialisation des plantes médicinales au Kérala (Inde). Économie rurale, $n^{\circ} 343$, p. 53-70.

- Dejouhanet L., 2017. Tourism in the mountains of Central Kerala (South India): at the Crossroads of attitudes toward forest populations. Journal of Alpine Research, vol. 105, $\mathrm{n}^{\circ} 3$ / Le tourisme dans les montagnes du centre du Kérala (Inde du Sud) : à la croisée des regards posés sur les populations forestières. Journal de Géographie Alpine, vol. 105, nº 3.

\section{RÉMI DE BERCEGOL}

Rémi de Bercegol, remi.debercegol@cnrs.fr, is a Research fellow at the Centre National de la Recherche Scientifique (CNRS) and a member of research unit Prodig. He recently published : - de Bercegol R., 2019 [1ère ed. 2010]. Small Towns and Decentralisation in India. Rawat Publications [1ère ed. Springer], $246 \mathrm{p}$.

- de Bercegol R., Gowda S., 2018. Waste and Energy Nexus: Rethinking the modernisation of waste services in Delhi. Urban Studies, Special Issue on 'Urban Nexus', June 2018.

- de Bercegol R,, 2018. Les enjeux de la valorisation des déchets à Delhi. In Jaglin S, Debout L., Salenson I., (dir.), Du rebut à la ressource, Valorisation des déchets dans les villes du sud. Paris, AFD, p. 31-49. 